Krystyna Latawiec

Uniwersytet Pedagogiczny im. KEN

kala48@onet.eu

\title{
„Bezwstydne wstydy żarty” - poetyckie zabawy Janusza Szubera
}

\section{“The shameless jokes of shame:” Poetical Pranks of Janusz Szuber}

\begin{abstract}
The article discusses the humorous aspects of Janusz Szuber's poetry. Three main strategies are differentiated: minimizing the poet's role, linguistic play and "libertine" humour. The analysis of selected poems shows that the poet uses joke, word play and linguistic stylization. He draws on the baroque tradition, reusing the motif of vanitas. He employs the Old-Polish verse types and topoi, and refers to essentially humorous genres as e.g. the limerick. The passing of time and eroticism are treated with the distance of mild irony. As a conclusion to the discussion of the different practices aimed at making the reader laugh, the article cites a humorous poem about the postmortem pose of a countess on her tomb in Dukla.
\end{abstract}

Keywords: Janusz Szuber, humour, poetic joke, stylization, baroque, vanitas, Dukla

Streszczenie: W artykule omówione zostały humorystyczne aspekty poezji Janusza Szubera. Wyodrębniono trzy podstawowe strategie: minimalizowanie roli poety, zabawy filologiczne, „libertyński” dowcip. Analiza wybranych wierszy dowodzi, że twórca operuje żartem, zabawą słowną, językową stylizacją. Sięga do tradycji barokowej, odnawiając motyw vanitas. Korzysta ze staropolskiej wersyfikacji i topiki, przywołuje gatunki ze swej istoty humorystyczne, takie jak limeryk. Z dystansem łagodnej ironii traktuje przemijanie i erotykę. Za podsumowanie praktyk obliczonych na wywołanie u czytelnika uśmiechu posłużył żartobliwy utwór o pośmiertnej pozie hrabiny na nagrobku w Dukli.

Słowa kluczowe: Janusz Szuber, humor, poetycki żart, stylizacja, barok, vanitas, Dukla

Zacytowana w tytule fraza pochodzi z tomu 19 wierszy ${ }^{1}$ i niech posłuży tu za swego rodzaju motto interpretacji ukierunkowanej na przegląd humorystycznych aspektów utworów, które wyszły spod pióra Poety z Sanoka. Najczęściej bywa

1 J. Szuber, To [w:] 19 wierszy, Lesko 2000. Cytuję za wyborem: J. Szuber, Lekcja Tejrezjasza i inne wiersze wybrane, Kraków 2003, s. 86. Wiersze cytowane z tego tomu będę oznaczać skrótem LT, podając tytuł i numer strony w tekście głównym. 
on czytany w ramie solennej powagi, która zresztą dobrze przylega do stylu uprawianej przez Szubera poezji. Umieszczana w nurcie obiektywistycznym (realistycznym), jeśli chodzi o jej respekt wobec rzeczywistości, jak też w kręgu nowego klasycyzmu, gdy rozpatrywać jej kunszt poetycki, twórczość ta ma już całkiem solidną recepcję ${ }^{2}$. Krytycy sięgają nierzadko po określenia „styl wzniosły”, „model poezji wysokiej" Pewne podstawy do traktowania tejże w trybie podniosłym daje sam poeta, gdyż opowiada się po stronie klasycystycznych zasad umiaru i stosowności, a przeciw tak mocno dziś ekspansywnej ekspresji rodem z dionizyjskich i romantycznych pokładów sztuki spod znaku Herbertowego Marsjasza ${ }^{4}$. Obstawanie przy pewnej odświętności poezji nie wyklucza wszak podejścia ludycznego, zdystansowanego względem rozmaitych ideologii, które zwodzić mogą na manowce pozornego uniwersalizmu, podczas gdy Szuber ceni sobie postawę nominalistyczną. Idąc tą droga, potrafi dostrzec na bardzo konkretnych przykładach paradoksy bytu, aby następnie szukać ich słownych ekwiwalentów w grach językowych, stylizacjach, zabawnych komentarzach czy puentach. Zatem humor poetycki nie musi być przeciwieństwem powagi, ale jej komplementarnym uzupełnieniem, mającym równie ważny wymiar poznawczy jak dociekania prowadzone w tonacji serio5.

Przywołane tu „bezwstydne wstydy żarty” to cytat z wiersza o sprawach ostatecznych, nawiązującego tytułem To do Czesława Miłosza. Podobnie jak u Starego Mistrza refleksja poważna sąsiaduje u Szubera z nutą żartobliwą, czasem nawet frywolną. I tak rekwizyty wyjęte z liturgii katolickiej, podane tu w stylizacyjnej ramie wersyfikacyjnej, przypominają o marności żywota, który znajduje swój efektowny finał w żałobnym fiolecie i przygasłym złocie monstrancji:

Fiolety bandolety coraz bliżej do mety

i odmrożone pięty

przez zaśnieżone adwenty

bezwstydne wstydy żarty gra w karty - zabrakło karty odpusty zapusty gwarancje pogasły sczerniałe monstrancje (...)

2 Zob. T. Cieślak-Sokołowski, „Mój wszechświat uczyniony”. O poezji Janusza Szubera, Kraków 2004; Poeta czutej pamięci. Studia i szkice o twórczości Janusza Szubera, red. J. Pasterska, M. Rabizo-Birek, Rzeszów 2008; A. Sulikowski, Epos sanocki Janusza Szubera, Szczecin 2010.

3 J. Orska, Mistrz, czyli sztukmistrz, „Odra” 2000, nr 11, s. 117.

4 Wypowiedzi J. Szubera cytuje obficie T. Cieślak-Sokołowski, dz. cyt., s. 130.

${ }^{5}$ Krytycy potrafią docenić intelektualną wartość poetyckiego humoru w poezji nowoczesnej. Zob. W. Ligęza, „Żart jest najlepsza dla mnie rekomendacja powagi”. O humorze poetyckim oraz Wistawy Szymborskiej zabawach stowem i obrazem, „Polonistyka. Innowacje” 2015, nr 2. 
gulgoty żaboty zgagi

koniec szumnej parady

czekają z rydlem i kosą

Zzuj meszty - w to wkracza się boso

(To, LT, s. 86)

Kontemplacja toposu vanitas ma wyraźnie estetyczny charakter, zważywszy na wyszukaną formę wiersza stylizowanego na dawny sylabik, wzmocniony parzystymi rymami. Płynnie zrytmizowany tekst można uznać za rytualne pożegnanie doczesnego życia, wywiedzione z katolickiej liturgii, oczywiście przefiltrowane przez medytacyjny namysł nad przemijaniem pióra księdza Józefa Baki. Wstydy i żarty żywota ustępują przed żałobnymi insygniami, ale to dopiero w finale, gdy zamyka się definitywnie czas uciech.

Barokowa reminiscencja, związana tak ściśle z antynomicznym pojmowaniem kondycji ludzkiej, nie wyczerpuje jednak sensów cytowanego wyżej utworu Szubera. Wszak powaga i żart pospołu określają świadomość nowoczesnego podmiotu, akceptującego istnienie nieusuwalnych sprzeczności między tym, co wzniosłe, i tym, co zabawne. Jawna stylizacja To znamionuje postawę zdystansowaną, ale przecież nie osłabia dotkliwego faktu przemijania, tyle że nadaje mu kunsztowną formę językową dzięki archaizmom (fiolety, bandolety, żaboty, meszty), a rytm wiersza i rymy przydają płynności zjawisku schodzenia ze sceny żywota, czyniąc je niemal tanecznie swobodnym. I choć Janusz Szuber nie jest ironistą destrukcyjnym ${ }^{6}$ ani nie szuka satysfakcji moralnej w sarkazmie, to jednak nie stroni od humoru poetyckiego, który stanowi istotny składnik jego komunikacji z czytelnikiem i tego, co Jacek Łukasiewicz nazwał towarzyskością jego poezji ${ }^{7}$. Humor w odróżnieniu od ironii cechuje życzliwe nastawienie do ludzi, nawet jeśli dostrzega się ich słabości czy nawet dziwactwa. Nie ośmiesza, lecz paradoksalnie afirmuje widzialny świat. Wszak znane i polszczyźnie niemieckie słowo „Witz” pokrewne jest czasownikom „widzieć” i „wiedzieć”, jak przypomina Manfred Geier ${ }^{8}$.

Umieszczenie przez poetę rzeczy świata tego w modalnej ramie językowej gry i zabawy traktuję zatem jako manifestację autorskiej wiedzy o naszej kondycji tu i teraz, choć z perspektywą otwartą na zmediatyzowaną w znakach kultury przeszłość. Uśmiech wyzwala inwencję twórczą, sprzyja poszukiwaniu zaskakujących pomysłów i słownych ujęć dla zjawisk już po wielekroć

${ }^{6} \mathrm{Na}$ temat rodzajów śmiechu, jego paradoksów, roli kulturotwórczej zob. R. Nycz, Gest śmiechu. Z przemian świadomości literackiej początku wieku XX [w:] tegoż, Język modernizmu. Prolegomena historycznoliterackie, Wrocław 2002, s. 225-258.

7 J. Łukasiewicz, Janusz Szuber - poeta towarzyski [w:] Poeta czutej pamięci..., dz. cyt., s. 19.

${ }^{8}$ M. Geier, $Z$ czego śmieja się mądrzy ludzie. Mata filozofia humoru, thum. J. Czudec, Kraków 2007, s. 100. 
nazwanych, by przydać poetyckiemu opisowi waloru niespodzianki. „Jakością ludyczną zabarwiają się u Szubera wypowiedzi o rzeczach, szczególnie gdy bezinteresowny śmiech łączy się z poetyckim konceptem" - pisał Wojciech Ligęza o spoufaleniu poety z przedmiotami'. Powstaje swego rodzaju intymna więź podmiotu ze światem, postrzeganym życzliwie i we wspólnocie z czytelnikiem. Humor nie służy wtedy manifestacji wyższości ego nad materią rzeczy i ludzi, ale sprzyja komunikacji w realiach codziennych i odświętnych zarazem, gdyż zabawa sama w sobie jest czasem świętowania. Dzięki temu poezja nabiera ludycznej lekkości, pozwala znieść niewygody losu i cieszyć się tym, co daje uważna obserwacja poczyniona z żartobliwego dystansu, a następnie przekazana odbiorcy w zaskakującej go formie językowego czy obrazowego pomysłu. Wśród licznych sposobów wywoływania efektu zdziwienia są takie, które proponuję ująć w następujące kategorie: 1) minimalizowanie roli poety, 2) zabawy filologiczne, 3) „libertyński” dowcip.

\section{Minimalizowanie roli poety}

W osobistym wierszu skierowanym bezpośrednio do Wieszcza Juliusza Janusz Szuber wyznaje: „Jestem zjadaczem chleba,/ który nigdy nie miał ambicji bycia aniołem"10. Opowiada się po stronie realizmu jako swoistego remedium na romantyczne przebóstwienie natury i ludzi. Nakierowanie uwagi na realia pomaga uwolnić wyobraźnię od aury niezwykłości, oddalającej od spraw pospolitych. Zatem nie wzloty poetyckiej fantazji, ale ku ziemi skierowane zmysły dostarczają impulsów wyobraźni materialnej, skłaniają do innowacji językowych, utrzymanych jednak w ryzach gramatyki (dowodem na to często wymieniane przez poetę zaimki dzierżawcze czy czas imperfektum). Realizm $\mathrm{w}$ połączeniu $\mathrm{z}$ dyscypliną słowa ogranicza pole dla śmiechu pochodzącego z czystego fantazjowania, powściąga też pokusę umieszczenia siebie w napowietrznych rejonach ponad trywialną rzeczywistością zjadaczy chleba. A to w niej właśnie należałoby umieścić punkt obserwacyjny, z którego dobrze widać zabawne strony egzystencji, jak też nieprzystawalność doń nazbyt sformalizowanych kategorii pojęciowych. Humorystyczne podejście do własnej osoby i do świata wyzwala myśl od automatyzmów, czyni ją giętką, a na polu poezji rozwija swobodnie jeden z jej atrybutów, mianowicie ludyczną towarzyskość.

Na dystans Janusza Szubera do własnego pisarstwa krytycy już wskazywali, wyodrębniając frazy, których sednem są słowa: „imitator”, „przedrzeźniacz”, „urzędnik”. Z nich wyłania się autoironiczny portret niechętnego patosowi

9 W. Ligęza, Rzeczy i opowieści. O poezji Janusza Szubera [w:] Poeta czutej pamięci..., dz. cyt., s. 203.

${ }^{10}$ J. Szuber, Niczego więcej [w:] tegoż, Powiedzieć. Cokolwiek, Kraków 2011, s. 85. 
poety ${ }^{11} \mathrm{i}$ pojawia się sugestia, iż w ten sposób daje on odmienny od klasycznego wariant toposu exegi monumentum ${ }^{12}$. Istotnie, przekonanie o wyjątkowości poezji bywa dziś rzadkie, a jeśli już się ujawnia, to w przypadku młodych adeptów pióra. Dojrzały twórca ma zazwyczaj świadomość nieuchronnej wariacyjności motywów, powtarzalności fraz i stylistycznych figur, które oferuje skodyfikowana ars poetica. Prócz niej jest jeszcze sfera mentalna „baśniowych krain”, jak te wodzące na pokuszenie sentymentalizmu galicyjskie i bukowińskie obrazki wywiedzione z przewodnika kolejowego sprzed pierwszej wojny ${ }^{13}$. Łatwo mogłyby poprowadzić wyobraźnię w dziedzinę miłej sercu czytelnika fantazji, wciąż żywej z uwagi na kultywowany w pogalicyjskiej przestrzeni kulturowej mit habsburski.

U Janusza Szubera nie ma jednak prostej repetycji galicyjskiego tematu. Aby nie dać się zwieść mitotwórstwu, poeta zmierza do puenty, w której słowo „karać” niesie dwojaki sens: 1) ostrzega pasażerów pociągu z czasów belle époque, że zabieranie przewodnika z przedziału będzie karane; 2) komentuje wiek XX, w którym „zostaliśmy ukarani dotkliwie i przykładnie”. Czasownik „karać” oscyluje zatem między różnymi znaczeniami odsyłającymi do czynności urzędowej za złamanie przepisu, kary za grzechy (tu raczej za ten czas niewinności sprzed dwu wojen światowych i rewolucji), wreszcie tej wymierzanej ludziom przez historię na ślepo i bez wyjątków. Ostatni z wymienionych tu sposobów karania nie zna subtelności rozróżnień ani umiaru, nadto jest to sankcja niewspółmiernie wysoka w stosunku do niewielkiego w końcu przewinienia, jakim było przywłaszczenie sobie przewodnika, własności c.k. Dyrekcji kolejowych. Gra możliwymi znaczeniami słowa „karać” ma tu odcień z lekka melancholijny, gdyż powrót do mitu, choć kuszący, okazuje się nawet nie tyle niemożliwy, co niestosowny w obliczu tragicznego końca tamtego świata. Odsłonięcie w puencie intencji związanej ze słowem tak nośnym semantycznie ustawia głos poety na „niskim” tonie, czyli blisko materialnej strony egzystencji, która podlega wprawdzie prawu przyjemności podróżowania, ale i wiszącej nad nią kary za doznawanie tejże. Przyjmując postawę skromnego komentatora, poeta wypełnia swoje zobowiązanie wobec przyziemnej wyobraźni, co w tym wypadku oznacza szczególny rodzaj wierności wobec tych, którzy byli tu przed nami, a których pamięć podtrzymuje wertowanie przewodnika kolejowego z czasów, gdy po Galicji podróżowano jeszcze bez wiedzy o zawieszonym już nad nią wyroku historii.

11 Zob. T. Cieślak-Sokołowski, dz. cyt., s. 153-154.

12 Zob. T. Chomiszczak, „Jednogtośnie wybrany naszym dyżurnym guru”. Od ironii poetyckiej do poezji ironii Janusza Szubera, „Zeszyty Archiwum Ziemi Sanockiej. Rocznik” 2003, nr 3, s. 85.

13 J. Szuber, Nieruchoma podróż [w:] tegoż, O chtopcu mieszającym powidta. Wiersze wybrane 1968-1997, Kraków 1999, s. 22-23. Wiersze cytowane z tego tomu będę oznaczać skrótem Och, podając tytuł i numer strony w tekście głównym. 
W zgodzie z przyziemną wyobraźnią, a nie w romantycznym z nią konflikcie, kreuje Szuber wizerunek poety jako kronikarza. Szuka inspiracji w konkretach, jak choćby wspomniany wyżej przewodnik po Galicji, jednak wychodzi poza wąsko rozumiany realizm, tyle że nie w stronę fantazji, a raczej zdystansowanej autoironii. I choć „marny ze mnie kuglarz-akrobata” - wyzna w wierszu Kto? (Och, s. 89), to jednak znaczy swym pisaniem sygnaturę indywidualną („formę odciska”) na doświadczeniu zbiorowym zawartym w języku i w obrzędach. Nazwie siebie szekspirowskim Kalibanem, który od czasu do czasu głosem Mirandy chwali cuda i wdzięk ludzkich spraw (Splatając się w strumienie, LT, s. 31). Jak krotochwilny trefniś ogląda „miłosne pląsy planktonu na ekranie”, komentując biologię rozmnażania słowami: „Pieśń nad pieśniami słonych glonów" (O najjaśniejszy, najjaśniejsza, LT, s. 39). Eros zobaczony w wodnych odmętach nie ma w sobie nic z wyjątkowości przydanej mu przez poezję. Nadto opatrzony nutą wzniosłą, wywiedzioną z repertuaru miłosnych fraz, obrazek ten wywołuje efekt komiczny, jeśli skojarzyć pląsy planktonu $\mathrm{z}$ poczynaniami ludzi $\mathrm{w}$ sferze zalotów ${ }^{14}$. Komedia życia nieustannie zadziwia uważnego obserwatora biegu rzeczy świata tego i co za tym idzie skutecznie zniechęca do nazbyt poważnego traktowania własnego w tym spektaklu udziału. Jeśli już mówić o losie gatunku czy pojedynczych jego osobników, to z pewną dozą humoru, aby uniknąć indywidualistycznej ostentacji czy też tak dziś ekspansywnej ekshibicji.

Walor humorystyczny mają też stylizowane autokreacje, dla których podstawą jest wzór wersyfikacyjny. I tak wzięta z Wacława Potockiego fraza o kaznodziei idącym do fary posłużyła Szuberowi za punkt wyjścia zabawnego wierszyka Poszóstnie przez Bieszczad, w którym miarą dla kroku w stronę fary i dla rytmu wiersza jest szóstka:

Jestem jaki jestem:

Weteran-scholastyk.

Po wertepie szuram

W trzewikach przyciasnych

Do nieba niespieszno, tym bardziej do piekła.

Przez ucho igielne

Wielbłąda przewlekam ${ }^{15}$.

${ }^{14}$ Humorystyczny zabieg Szubera wykazuje pewną analogię do tego, również humorystycznego fragmentu wiersza Wisławy Szymborskiej W rzece Heraklita, w którym identyczne z ludzkiego punktu widzenia ryby składają sobie miłosne wyznanie: „O najpiękniejsza z ławicy”. W. Szymborska, Wiersze wybrane, Kraków 2005, s. 104.

${ }^{15}$ J. Szuber, Poszóstnie przez Bieszczad [w:] tegoż, Powiedzieć. Cokolwiek, dz. cyt., s. 38. 
To tylko dwie strofy zrytmizowanego, regularnego tekstu o rymach wybrzmiewających nie natrętnie, choć wyraźnie. Przyjemność lektury wydaje się w takim przypadku analogiczna do przyjemności pisania, które jest niczym ćwiczenie pióra $\mathrm{w}$ metrum dawnych poetów. Niespodzianka zafundowana czytelnikowi pochodzi ze zdziwienia, że i dziś można użyć regularnej miary, by wykreować własną tożsamość według utartych wzorów rymotwórczych, nawet sięgnąć po biblijny frazeologizm dla jawnie fingowanej autoprezentacji. Zdolność do udawania (pastiszu, parodii) pochodzi ze świadomości, że zarówno poezja, jak i jej twórca są wytworem fikcyjnej sytuacji, której kres położy zamknięcie narzędzia pracy: „Koniec. Wyłącz laptop,/ Na dzisiaj wystarczy”" Zarówno czas literackiego fingowania tożsamości, jak i czas zabawy są wyłączone z powszedniego biegu zdarzeń. W ramie święta odnawia siły witalne homo ludens, a poeta $\mathrm{w}$ intertekstualnej przestrzeni języka prowadzi grę $\mathrm{z}$ wizerunkiem własnym i z tymi, które zapisała tradycja, a z użyciem nowej techniki (laptop) podtrzymuje współczesność.

\section{Zabawy filologiczne}

Komiczna waloryzacja przedmiotu opisu wymaga biegłości w sztuce słowa, gdyż to właśnie za sprawą rozwoju retoryki doszło do zatarcia granicy między żartem a powagą ${ }^{17}$. Dowcipne sformułowania dają czytelnikowi chwilę odprężenia, pozwalają okiełznać lęki i samotność w obliczu niepoznawalnego świata. W braku bezpośredniego doń dostępu sięgamy po filologię, która fortunnie stosowana niesie pewien rodzaj konsolacji i buduje poczucie więzi z jej użytkownikami, tymi z czasów minionych i tymi obecnymi. Zatem zabawa w „zamianę zaimków” to rodzaj „filologicznego” świętych obcowania, jak puentuje poeta wiersz Fienna Petczyna (LT, s. 24).

Spośród możliwości oferowanych przez gramatykę Szuber dość często wybiera powinowactwa brzmieniowe: „Z prawego łoża, z łona szlacheckiego” (Klara, Och, s. 37), „Attyki architrawy, sgraffiti i baszty” (Historia, z której nic nie wynika, Och, s. 97), "krotochwilny tlenu trefniś” ( $O$ najjaśniejszy, najjaśniejsza, LT, s. 39), „W wątpiach żarzące zwątpienie” (Mur, LT, s. 73). Potrafi też zaskoczyć ciekawym rymem, aliteracją, sugestią etymologicznego pokrewieństwa wyrazów. Rzeczywiste czy pozorne analogie dają wrażenie jedności w obrębie wspólnoty użytkowników języka, co nie znaczy, że powiązania te mają wyłącznie abstrakcyjno-formalny charakter. Filologia to mocna podstawa, skoro można w niej zawrzeć geografię powiatu, genealogie przodków i ślad osobistego doświadczenia. Przepisać raz jeszcze to, co znane z lektur

16 Tamże, s. 39.

17 Zob. E.R. Curtius, Literatura europejska i tacińskie średniowiecze, tłum. A. Borowski, Kraków 1997, s. 428. 
i rodzinnych anegdot, opatrując zabawnym i jednocześnie refleksyjnym komentarzem. Podobne brzmienie słów, rzeczywiste bądź kreowane, przynosi jednak coś więcej niż tylko fonetyczne powinowactwa, sugeruje mianowicie więź (społeczną, literacką, metafizyczna) z uniwersum kultury. U jej początku wąż (zbieżność brzmień: wąż-więź), teraz już nieco oswojony, mruga porozumiewawczo na poetę-chudopachołka „ukrytego w kącie z hubką i krzesiwem” (Historia, z której nic nie wynika, Och, s. 97). Z takiego rodzaju porozumienia, dwuznacznego i na wpół skrytego, rodzi się humorystyczny dystans do poważnych tematów przemijania, grzechu czy wstydu.

Aby je obłaskawić, sięga Szuber po stylizacje wersyfikacyjne, ujmując w nawias poetyckiej zabawy powagę spraw ostatecznych. Szczególne miejsce $\mathrm{w}$ dialogu prowadzonym $\mathrm{z}$ tradycją barokową zajmuje tomik 19 wierszy ${ }^{18}$. Wykreowany tu na użytek stylizacji bohater to „moralitetu mieszkaniec” (Sam, LT, s. 89), który spogląda na zanurzonych w konkrecie czasu i miejsca z perspektywy wanitatywnej, rozweselając nazbyt postny obraz żywą scenką wziętą ze świętych malowideł:

\section{W cerkwiach na ławkach kolatorskich \\ Kości, sądu czekające, w jaką taką \\ Całość składać i w ciała przyoblekać. \\ O, jakie huczne świętych obcowanie! \\ Każdy z nich osobny, krwisty i rumiany \\ Od słońca, co właśnie za Bieszczad zachodzi \\ (Do Ryszarda Schramma, LT, s. 90)}

Po niegdyś żyjących zostają tylko kości, natomiast w przestrzeni metafizycznej święci bawią się jak na hucznym weselu, tyle że zamienionym w „huczne świętych obcowanie”. Obie sfery: kości umarłych i rumiane ciała świętych pozostają ze sobą w ścisłym związku jak czas pokutny i czas radosny, następujące po sobie w ciągu pokoleń praktykujących obrzędy codzienne i religijne. Między postem a karnawałem, płomieniem piekielnym a czarcim zamtuzem zamyka się dramat egzystencji naznaczonej przez średniowieczno-barokowe antynomie. Do dziś obrazy wywiedzione z tego kręgu kultury zachowują sugestywność emocjonalną, nawet jeśli straciły sens moralistyczny. Poeta współczesny używa ich niczym gotowego konceptu, stabilnego i wyrazistego, choć zarazem zmodyfikowanego dzięki kontaminacji fraz: „huczne wesele" i „świętych obcowanie”. Rezultatem takiego zabiegu jest humor kontemplacyjny, łączący refleksję nad przemijaniem z uśmiechem wywołanym językowym „przeinaczeniem”.

Dysponujący regułami gramatyki i poetyki komentator $\mathrm{z}$ wierszy Janusza Szubera potrafi w osobliwy sposób nazwać powszedniość ludzkich

${ }^{18}$ J. Szuber, 19 wierszy, dz. cyt. 
zatrudnień. Kiedy obserwuje zaabsorbowanych zakupami klientów centrum handlowego, to widzi „ich postne kości,/ Łaskotane pazurkami żuków-grabarzy" (Zachtannie, w zachwyceniu, LT, s. 81). W niedzielną zabawę na karuzeli wplata motyw makówki-trupiej główki (Oktostych, LT, s. 82). Sięga po oksymoron: „Kruk stąpa po wrzącym śniegu”, pytanie retoryczne: „Kto potępieniu zaradzi,/ Z objęć wyrwie szkaradnych?”, antynomiczne obrazowanie (kulig i karawan pogrzebowy). Posługuje się stałymi epitetami: grzech upadły, płomień wszeteczny, szkaradna śmierć. Otwarcie naśladuje rymy księdza Józefa Baki: „W Erosa uprzęży grzecznej:/ Niestateczne w kształcie statecznym” (Wyznanie [II], LT, s. 88); „- Co sądzone, nie unikniesz,/ Rychło do losu przywykniesz" (Kto mi powie, LT, s. 91). W tak jawnej imitacji stylu poezji barokowej kryje się podtekst pastiszowy. Naśladując rytm i frazę dawnego rzemiosła wierszowanego, pozostaje Szuber kuglarzem (jak sam o sobie mówi), sztukmistrzem słowa, które służy mu za materiał do literackiej gry z tradycją. Z barokiem łączą go też tematy wanitatywne i pokutne, motyw kości, ciała rozebranego z cudzych piórek w obliczu śmierci. Dostarcza ich obficie poezja Daniela Naborowskiego, Zbigniewa Morsztyna czy Olbrychta Karmanowskiego ${ }^{19}$.

Barokowa przestrzeń intertekstualna oferuje też pewien wzór antropologiczny, mianowicie człowieka pozostającego we władaniu zmysłów i jednocześnie odczuwającego z tego powodu własną grzeszność. A napięcie między tymi biegunami to źródło opozycji, na których poeta buduje pastisze. Wprawdzie nie wyłania się z nich nowa jakość poznawcza, ale samo ich przypomnienie kieruje uwagę na topos „życia oddanego we władanie żywiołów”. Skoro jednak wariacyjne przepisywanie tematu pochodzi od współczesnego intelektualisty, to można domniemywać, że stoi za tym zmysł łagodnej ironii. Nie tej nacechowanej masochistycznie, gdyby roztrząsania nad marnością traktować serio, ale rodzaj zdystansowanego humoru w gruncie rzeczy afirmującego niezmienny stan rzeczy i odpowiadający mu styl barokowej kontemplacji grzesznego żywota. Przedkładając czytelnikowi zrytmizowany wdzięk dawnej stylistyki, poeta aktualizuje istotne dla ówczesnej refleksji poczucie rozbieżności między zmysłowym doświadczaniem świata a jego religijnym odpowiednikiem w dziedzinie wyższej duchowości. Świadomie buduje pewną fikcję artystyczną, udając z dużym powodzeniem Bożego prostaczka podążającego za pożądliwościami ciała i zarazem poddanego Pani Śmierci. A że fikcja ta jawnie pobrzmiewa „cudzym” głosem, to wolno przypuszczać, że stanowi rodzaj kostiumu-przebrania na użytek poetyckiej gry, powziętej ku uciesze i refleksji.

19 „Spróchniałe kości” Daniela Naborowskiego, lament nad kośćmi, które „wyschły od żałości" Zbigniewa Morsztyna, pieśń pokutna Olbrychta Karmanowskiego - to kilka przykładów. Zob. „I w odmianach czasu smak jest”. Antologia polskiej poezji epoki baroku, oprac. J. Sokołowska, Warszawa 1991, s. 135, 512. 
Paradoksy istnienia można obłaskawić żartem, nie z ludzi, lecz z sytuacji, w jakiej się znaleźli za sprawą owych paradoksów właśnie. Wiersze pokutne, rekolekcyjne czy pisane „ku przestrodze” w warstwie zewnętrznej (leksyka, wersyfikacja) powtarzają znany wzór, natomiast na planie komunikacji z czytelnikiem zachęcają do podjęcia medytacji nad komiczną figurą losu wydanego prawu przemijania. Jako zjawisko artystyczne humor ,jest tak samo poważną kategorią tworzenia, jak dramatyczność lub groza" ${ }^{20}$. Ożywcza vis comica osłabia powagę spraw ostatecznych, ukazując je w ramie stylizacyjnego dystansu. Nie traci przy tym wartości moralistycznej, rozumianej na sposób nowoczesny jako igranie z tym, co wzniosłe, jednak nie po to, by je zdegradować, ale by zachować męstwo wobec nieuniknionego kresu żywota.

Konceptyzm stylizowanej na barok poezji Szubera przywodzi na myśl siedemnastowieczną kategorię „wit” - w staropolszczyźnie „dowcip”. Jednak nie w jego normatywnym sensie, ale jako pomysł łączący w jedność aspekty życia i umierania, o których można mówić w taki sposób, aby wywołać efekt niespodzianki i swoistej przyjemności intelektualnej. Wesele i taniec zmarłych, odmierzanie kroków w stronę śmierci czy rozbieranie ciała ze stroju to materialne odpowiedniki pojęć metafizycznych, których nowoczesny poeta raczej nie używa wprost. Ich duchową zawartość transponuje na konkret cerkiewnego malowidła, na rytm wiersza czy też rzutuje w antynomiczne obrazki i anegdoty. „Słowne igraszki” nie wydają się tylko ćwiczeniem w zakresie stylu, ale niosą przekaz ważny dla uznania pojedynczego losu za część większej kulturowej całości. Tym samym istnienie przestaje być absurdalne w egzystencjalistycznym jego rozumieniu. Jeśli nawet trudno mu przyznać status wyjątkowy, to przynajmniej uznajmy za możliwe, że spełnia się w wymiarze komunikacyjnym nie tylko tu i teraz, ale także w dialogu z duchami umarłych poetów. A jeśli chodzi o żywych, to obserwacje poczynione przez Szubera w markecie, cerkwi czy choćby przed telewizorem nabierają pod jego piórem konsystencji zjawisk istotnych, niemal substancjalnych mimo ich przygodności. Nie można wykluczyć, że to świat natury i człowieka pełen jest „konceptów”, które dostrzega uważne oko obserwatora i daje im odpowiednik w budzących zdziwienie słownych transpozycjach i zestawieniach.

\section{„Libertyński” dowcip}

Umysł wyrafinowany szuka podniety w artefaktach kultury dostarczających przyjemności zmysłom. Nie zawaha się sięgnąć po słowa z dziedziny erotycznej (zamtuz), zasugerować możliwość swawolnego odczytania niewinnej scenki z lampą-konkubiną-modliszką, zaprosić do kompanii w domu pokus. Afirmację ciała i jego pożądliwości łączy z humorem, co sprawia, że Eros nie jawi

${ }^{20}$ A. Grzymała-Siedlecki, cyt. za: R. Nycz, Gest śmiechu..., dz. cyt., s. 229. 
się wyłącznie jako grzeszny, ale nabiera cech przypisanych mu przez uwolnionego z więzów poprawności obyczajowej wolnomyśliciela. Przy czym nie chodzi tu o ponury i krańcowy w istocie libertynizm z ducha Markiza de Sade ani o propagowanie moralnej swobody w imię politycznie pojmowanej wolności. Raczej o pierwiastek epikurejski w traktowaniu spraw ciała i oprawy towarzyszącej realizacji jego pragnień ${ }^{21}$.

Podejście Janusza Szubera do erotyki zasadza się na tej dyspozycji intelektualnej, która skłania do żartu, raz bardziej stonowanego, innym razem otwarcie obscenicznego. To jeszcze jeden z kostiumów wybieranych z garderoby kultury na okoliczność zabawy poetyckiej, rozluźniającej sztywny gorset powściągliwości. I nie ma w tych praktykach „libertyńskich” nic pospolicie wulgarnego, gdyż stoi za nimi długa tradycja Erosa opisanego przez filozofów i poetów. Nie sposób sprowadzić libertynizmu do „zbanalizowanej wersji cielesności" ${ }^{2}$, zwłaszcza gdy mowa o jego erudycyjnej wersji, przefiltrowanej przez nowoczesną świadomość otwartą na dziedzinę seksualną. Ujmowana niegdyś w sztafażu pastersko-dworskim zmienia się w XVIII wieku „w sferę trzeźwego, nawet cynicznego realizmu obyczajowego i psycho-seksualnego"23. Znika erotyka wyidealizowana, a jej miejsce zajmuje obyczajowy realizm w różnych jego odmianach, także rozrywkowym i satyrycznym. I tak było aż do momentu, gdy nadeszła moda romantyczna: „lansująca styl sentymentalnych westchnień, miłosnych modłów i czysto duchowych uniesień w miejsce libertyńskiego traktowania spraw erotyki jako należących przede wszystkim do sfery fizjologi" ${ }^{24}$.

Niechęć do poezji „szczerych uczuć” znamionuje czasy nam współczesne, co skłania do szukania powinowactw z przedromantyczną tradycją pisania o Erosie. Jeśli nadto tematyce tej towarzyszy biegłość formalna, to jest to mocny argument przemawiający za uwolnieniem jej od konwenansu obyczajowej przyzwoitości i za potraktowaniem w kategoriach żartu towarzyskiego. Janusz Szuber dowiódł udatnie warsztatowej sprawności w tej dziedzinie, pisząc cykl „bezwstydnych” limeryków Emeryk u wód (gra słów: Emeryklimeryk). Spośród zamieszczonych w nim sprośnych wierszyków-żarcików zacytuję ten, z którego jasno wynika, że do komunikacji międzyludzkiej opartej na obscenach niezbędna jest znajomość słownictwa rodem z francuszczyzny

21 Żartobliwe, jak też poważne podejście J. Szubera do ciała opisuje Józef Nowakowski, który twierdzi, iż jest to motyw łączący dwa sprzeczne walory tej poezji: „zachwyt i rozpacz, wiarę i niewiarę. Szczęście miłosne, które ma dawać młody Eros, zostaje podobnie jak miłość także zakwestionowane, a strefa wartości, w głównej mierze rodowych i rodzinnych, oczywiście także zuniwersalizowanych - przesuwa się na sferę ludzi starych lub zmarłych”. J. Nowakowski, Eros w poezji Janusza Szubera [w:] Poeta czutej pamięci..., dz. cyt. s. 34.

${ }^{22}$ A. Łysiak-Łątkowska, Konteksty zjawiska libertynizmu. Kilka uwag badawczych, „Acta Universitatis Lodziensis. Folia Philosophica” 2008, z. 21, s. 120.

${ }^{23}$ J. Łojek, Libertyńska literatura francuska w XVIII wieku, „Teksty” 1974, nr 1, s. 30.

${ }^{24}$ Tamże, s. 39. 
(minette-koteczka), inaczej wychodzi rym dość toporny i chybiony z punktu widzenia tejże komunikacji:
Pewna dama o imieniu Henrietta
chciała znaleźć rym do słowa „mineta”.
Wyraz rzadki i dotyczy seksu,
nieczytelny dla gminu i plebsu.
Wierszokleta podpowiedział jej, że „dieta”25.

Wiersz skomponowany został zgodnie z regułami gatunku, którym tak chętnie bawią się współcześni poeci. Szuber dołącza do ich grona, oferując czytelnikowi obeznanemu z tą formą poetycką zabawę nie „dla gminu i plebsu”, więc wyrafinowaną z założenia mimo jej nieobyczajnej frywolności.

Cyklem limeryków wpisał się poeta w bogatą już polską tradycję gatunku, choć może nie tak „plugawych” wierszyków, jak te sygnowane nazwiskiem Macieja Słomczyńskiego. Sytuuje się bliżej swawolnych utworów Wisławy Szymborskiej czy Stanisława Barańczaka. Nie epatuje Szuber nadmiarem wulgaryzmów ani dosadnymi określeniami. Zastępuje dosłowność kalamburem: „zoofil się po Tule tuła" (E, s. 36); korzysta z wieloznaczności słów: ,jednej pani doświadczali dwaj fizycy" (E, s. 12) - wszak fizyka to nauka na doświadczeniu oparta; zestawia wyrazy o podobnym brzmieniu, choć różne semantycznie: „śledził żonę”, która „śledzionę miała kiepską”, bo „słone śledzie razem z beczką/ pożarła" (E, s. 15). Nie jest mu obcy wisielczy humor - gdy Grzegorz Dorotę już posiadł w lasku, to wyznał leżącej na mchu: „Do ostatniego tchu/ Twój. I zawisł na pasku" (E, s. 34). Żartobliwe ze swej istoty limeryki bawią słownymi skojarzeniami i celną puentą. Przywołują poetykę facecji, „pieprznego” dowcipu, który niegdyśs nazywano witzem (Szuber przypomina ten słabo dziś obecny w polszczyźnie germanizm, E, s. 23). Utwory te są w równej mierze wyrazem poczucia humoru i sprawności warsztatowej poety. A że o przygodach ciała w nich mowa, to i śmiech tu frywolny, jak przystało na intelektualnego „libertyna”.

Umysł dowcipny potrafi zrobić dobry użytek z tego, co podsuwa mitologia ciała "prowadząca w głąb życia”"26. Odwrócenie wektorów od powagi uczonych ksiąg Arystotelesa, Akwinaty czy Kierkegaarda do uciech nazwanych dla żartu kuszeniem mistycznym skutkuje zawołaniem: „Hop, hop, młodzieńcze, prosimy do kompanii./ Odrzuć niepotrzebną wiedzę, która psuje rozum” (Dom pokus, Och, s. 64). Do sfery erotycznej odnosi się też anegdota o „baronie” udręczonym za życia przez homoseksualne pożądanie. I jemu w końcu dana jest nagroda w obrazku rajskiego antyszambru, „gdzie nastoletni/ pyszni serafini/ prowokująco uśmiechnięci/ demonstrują swoje młode/ i sprężyste tajemnice"

${ }^{25}$ J. Szuber, Emeryk u wód, Rzeszów 2012, s. 22. Następne cytaty z tego tomiku zaznaczam w tekście głównym, podając w nawiasie skrót E i numer strony.

${ }^{26}$ J. Nowakowski, Eros w poezji Janusza Szubera [w:] Poeta czutej pamięci..., dz. cyt., s. 41. 
(Barona portret trumienny, Och, s. 50-51). A że to portret trumienny, to żart nabiera charakteru dwuznacznie niepokojącego, gdy raj z duchowego przemienia się w hedonistyczny z sugestywną wizją pozaziemskich uciech cielesnych.

Poeta chętnie łączy sprawy ostateczne z kuszeniem jak najbardziej doczesnym, jakby te dwie sfery nie oddzielała przepaść nie do przebycia, a zaledwie różnica spojrzenia na udrękę pożądania „tu” i spokój spełnienia „tam”. Nie ma w tym deprecjacji samej śmierci, ale sceptycyzm wobec nazbyt rygorystycznego jej traktowania w nauczaniu moralistycznym. Zaświaty przewartościowane przez portret lubieżnego barona nabierają cech ludzkich, gdyż jest w nich miejsce na erotykę nienormatywną z teologicznego punktu widzenia. W tak pomysłowym przeinterpretowaniu motywu homoseksualnego można dostrzec przejaw nowoczesnego konceptu. Barokowa proweniencja wiersza o baronie nasuwa się samoistnie dzięki tytułowej frazie „portret trumienny”, ale bohater opowiedzianej tu anegdoty jest jak najbardziej dwudziestowieczny. Homoseksualne pożądanie czyni go męczennikiem ciała, a to zbliża jego kondycję do tej „niewolnika zmysłów” w dawnej poezji. Obecnie rozdarcie nie znajduje jednak wyjaśnienia w systemie pojęć metafizycznych, skoro nawet semantyka raju uległa przesunięciu w stronę hedonizmu.

\section{Zakończenie: Amalia w Dukli}

Podlegający prawu natury i przemijania żywot Jedermana zasługuje bardziej na życzliwy żart niż zgryźliwy sarkazm. Jeśli już łagodna ironia, to taka, do której zachęca sama portretowana postać swą prowokacyjną pozą, jak marmurowa Amalia z Brühlów Mniszchowa na nagrobku w dukielskim kościele Marii Magdaleny. Strojna w falbany lekko unosi głowę w półśnie, półrozmarzeniu, a książka (modlitewnik?) wypadła jej z rąk. Wsparta ręką o zagłówek oddaje się marzeniu mistycznemu czy erotycznemu. Przed Szuberem na ornamentykę rokokowego kościoła w Dukli zwrócili już uwagę Miron Białoszewski (Dukla Amaliowa, datowana na lata 1952-1976) i Jerzy Harasymowicz (Dukla z tomu Wesele rusatek, 1982) ${ }^{27}$. Komentarz dorzuca i sanocki poeta, dostrzegając aspekt erotyczny w upozowanej teatralnie sylwetce hrabiny, która nawet po śmierci ułożyła się na nagrobku w taki sposób, jakby właśnie oczekiwała na coś przyjemnego:

muszla z luster rokokowa bombonierka w czepku z książką w atłasowych pantofelkach tak umierać na oczach gawiedzi ${ }^{28}$.

27 Szerzej na ten temat z uwzględnieniem nadto Dukli Andrzeja Stasiuka w artykule: K. Latawiec, Dukla - omfalos i miejsce peryferyjne [w:] Od poetyki przestrzeni do geopoetyki, red. E. Konończuk, E. Sidoruk, Białystok 2012.

${ }^{28}$ J. Szuber, Dukla [w:] tegoż, Glina, ogień, popiót, Berlin-Toronto 2004, s. 14. 
We wznoszącą się linię intonacyjną ostatniego wersu i w antykadencyjne jego zakończenie wpisane zostało podszyte humorem zdziwienie w rodzaju zapytania: czy to wypada hrabinie tak dwuznacznie ułożyć się na pośmiertnym miejscu wiecznego spoczynku, jakby czekała w buduarze na kochanka? I to na oczach zwiedzających wnętrze kościoła turystów, że o wiernych uczestniczących w obrzędach liturgicznych nie wspomnę. Rokokowa ornamentyka kościoła pod wezwaniem Marii Magdaleny, postaci też ze zmysłową grzesznością powiązanej, sprzyja fantazji o zabarwieniu erotycznym. Marmurowa Amalia emanuje powabem ciała udrapowanego w strojną szatę, jak też intryguje rozmarzonym wyrazem twarzy, zamiast kontemplować vanitas. A że czyni to od ponad dwu stuleci w miejscu sakralnym, wprawdzie w bocznej kaplicy, ale jednak kościoła, nadto na widok wiernych czy zwiedzających wystawiona, to rzecz wydała się poecie nader pikantna, czemu dał wyraz w starannie dobranych słowach i w intonacji nacechowanej semantycznie. Nawiązał swoiste porozumienie („mrugnięciem oka”) z osiemnastowieczną arystokratką, która nawet post mortem kokietuje jak wytworna dama, a poeta rozpoznaje jej grę skrytą pod pozorem pośmiertnego zamyślenia.

Szuber sięgnął tu do rozpowszechnionego wśród osiemnastowiecznych elit hedonizmu, który jednak nie unieważniał pojęć chrześcijańskich, a nawet na sposób eklektyczny łączył z nimi epikurejską akceptację wolności intelektualnej i erotycznej. Wyrafinowane formy uwodzenia, ukształtowane we francuskich kręgach dworsko-arystokratycznych, oferowały podniety dla umysłu i zmysłów, co Janusz Szuber trafnie spuentował w sylwetce nagrobnej Amalii zarysowanej frazą z lekka ironiczną. Odnowił znak tamtego kodu kulturowego (rokokowa lekkość), używając jego środków estetycznych i właściwego dla erudycyjnych libertynów sceptycyzmu wobec spraw jednoznacznie kwalifikowanych jako ostateczne. Nie sposób bowiem oddzielić dostojnej powagi śmierci od swobodnej myśli, która nie zna ograniczeń formalnych. I niech ten podany dyskretnie i ze smakiem komentarz poety do nagrobka Amalii w dukielskim kościele posłuży za puentę niniejszych rozważań o humorystycznych aspektach wierszy Janusza Szubera. Komiczna waloryzacja świata nie powoduje jego degradacji, ale wytwarza płaszczyznę wspólną (towarzyską) dla życzliwego zainteresowania tym, co ludzkie.

\section{Bibliografia}

Chomiszczak T., „Jednogtośnie wybrany naszym dyzurnym guru”. Od ironii poetyckiej do poezji ironii Janusza Szubera, „Zeszyty Archiwum Ziemi Sanockiej. Rocznik” 2003, nr 3.

Cieślak-Sokołowski T., „Mój wszechświat uczyniony”. O poezji Janusza Szubera, Kraków 2004. Curtius E.R., Literatura europejska i tacińskie średniowiecze, tłum. A. Borowski, Kraków 1997. Geier M., Z czego śmieja się madrzy ludzie. Mata filozofia humoru, tłum. J. Czudec, Kraków 2007. 
"I w odmianach czasu smak jest". Antologia polskiej poezji epoki baroku, oprac. J. Sokołowska, Warszawa 1991.

Ligęza W., „Żart jest najlepszq dla mnie rekomendacja powagi”. O humorze poetyckim oraz Wistawy Szymborskiej zabawach stowem i obrazem, „Polonistyka. Innowacje” 2015, nr 2.

Łojek J., Libertyńska literatura francuska w XVIII wieku, „Teksty” 1974, nr 1.

Łysiak-Łątkowska A., Konteksty zjawiska libertynizmu. Kilka uwag badawczych, „Acta Universitatis Lodziensis. Folia Philosophica” 2008, z. 21.

Nycz R., Gest śmiechu. Z przemian świadomości literackiej początku wieku XX [w:] tegoż, Język modernizmu. Prolegomena historycznoliterackie, Wrocław 2002.

Od poetyki przestrzeni do geopoetyki, red. E. Konończuk, E. Sidoruk, Białystok 2012.

Orska J., Mistrz, czyli sztukmistrz, „Odra” 2000, nr 11.

Poeta czutej pamięci. Studia i szkice o twórczości Janusza Szubera, red. J. Pasterska, M. Rabizo-Birek, Rzeszów 2008.

Sulikowski A., Epos sanocki Janusza Szubera, Szczecin 2010.

Szuber J., 19 wierszy, Lesko 2000.

Szuber J., Emeryk u wód, Rzeszów 2012.

Szuber J., Glina, ogień, popiót, Berlin-Toronto 2004.

Szuber J., Lekcja Tejrezjasza i inne wiersze wybrane, Kraków 2003.

Szuber J., O chtopcu mieszajacym powidta. Wiersze wybrane 1968-1997, Kraków 1999.

Szuber J., Powiedzieć. Cokolwiek, Kraków 2011.

Szymborska W., Wiersze wybrane, Kraków 2005. 